\title{
Increasing Flesh Pigmentation in Growing Chickens
}

\section{F. T. Landeigora and P. Arenas Montale'}

\section{INTIRODUC'TION}

Pigmentation in chickens is largely controlled by the feed consumed. Bird $(1)^{2}$, Hammond and Harshaw (5), Heriman and Tigle $(6)$, and Ratcliff et al. (9) found that when growing chickens were fed rations consisting mainly of yellow corn, corn-gluten meal, and alfalfa-leaf meal, singly, they possessed brighter pigmentation in shanks, heaks, and skin in comparison to the respective parts of control chickens. Other workers demonstrated that feeds such as meat scraps, fishmeal, soybean-oil meal (2), and trace-mineral supplements (3) inhibited pigment deposition in growing chickens. The aforementioned feed ingredients are the primary components of poultry rations. The degree of pigmentation in chickens, then, depends upon the level and proportions of these various feeds in the poultry ration.

Various research work has repeatedly shown that feeds imparting color to egg yolk also enhance shank, beak, and skin pigmentation in chickens $(.4,7,11)$. Landágora $(8)$ recently demonstrated that the addition of whole achiote (Bexa orillana I.) seed to a basal ration fed to laying hens caused them to lay eggs with deeper colored yolks as compared with eggs from a group receiving no achiote seed. A study was undertaken to investigate whether supplementation of a basal poultry ration with achiote seed and canthaxanthin ${ }^{3}$, singly, would also impart brighter pigmentation to the shank, beak, and skin of growing chickens.

\section{EXPEIRIMENTAL PROCEDURE}

A total of 225 chickens was used in this study. In the first trial 50 straightrun Vantress chickens, scveral days old, were purchased from a local store. The ehickens were raised in the same pen and under similar feeding and management practices for $\overline{5}$ weeks, and then were divided into 2 groups at random, regardless of sex. Group 1 chickens received the basal ration and served as controls. Group 2 birds were fed the same basal ration (see tabulation p. 92) but with 0.5 -percent whole achiote-seed supplementation. Water was supplied at all times to both groups.

The ehickens were weighed in groups at the fifth weck on experiment and at the end of the feeding trial, the ninth week.

${ }^{1}$ Associate Professor, Faculty of Agriculture, University of Puerto Rico, Mayal güez, P.R., and Animal Industry (iraduate of 1961, respectively. The third trial was a special problem of the junior author during his senior year in College.

2 It alic numbers in parentheses rofer to Literature Cited, p. 97.

${ }^{3}$ Canthaxanthin was provided hy Hoffmann-Lat Roche, Nutley, X.J. 
The second trial was conducted by using 50 male sex-linked chickens to determine whether the observed higher average body-weight gain in the achiote-supplemented chickens, in contrast to the controls, was caused by the achiote-seed supplementation.

The same feeding, management, and procedure employed in the first trial were followed in the second. However, the chickens were wing-banded and weighed individually at the fifth and ninth week on experiment. The chickens in this trial were slaughtered also, and visual observations were made of the degree of pigmentation of the whole chicken carcass and of the fat deposits around various internal organs.

A third trial was conducted to compare the color-enhancing ability of achiote seed and of canthaxanthin upon the pigmentation of growing chickens. Several day-old straight-run Vantress chickens were used in this trial. The chickens were distributed into three groups at random. Twenty-five in group 1 served as controls; 50 chickens each were in the achiote group 2,

\section{The Basal Ration}

Ingredienis

Alfalfa-leaf meal

Ground yellow corn

Fishmeal

Noybean-oil meal ( 44 percent)

Corn-gluten feed

Cance molinsies

P'lizer premix ${ }^{1}$

Percent
5
56
10
19
5
5
.5

.5

${ }^{1}$ Pfizer premix 1 is an antibiotic vitamin-13-complex premix for growing chickens.

and in the canthaxanthin group 3. The canthaxanthin and achiote seed were added singly to the basal ration at a level of $12 \mathrm{gm}$., and $1 / 2$ pound per 100 pounds, respectively. The same feeding, management, and procedure employed in trial 2 were followed in the third trial, but visual observations on the pigmentation of the beak, shanks, and skin of the chickens in all groups were made daily in this trial. This was done to determine how soon the brighter pigmentation appeared in the experimental chickens. Only 10 chickens were killed from the canthaxanthin group, as the safety of this product in human food has not yet been cleared by the lood and Drug Administration.

\section{RESULTS AND DISCUSSIOX}

To simplify the discussion of the result and observation made in this study, it has been divided into trials.

\section{TRIAL 1}

Results of the visual observations of the various parts of a chicken are summarized in table 1 . The beaks and shanks of the chickens receiving 
achiote-seed supplementation were brighter yellow to orange color in comparison with the pale-yellow coloration of the beaks and shanks of the control birds. The overall pigmentation of the body of the achiote-fed chickens was deeper in color, and the degree of pigmentation was more pronounced at the base of feather, the area where feathers grow thickest, in contrast to a very light-yellow pigmentation, a breed characteristic, of the birds not fed achiote. The pale-yellow coloration noted in the shanks, beaks, and skin of the control birds can be partly attributed to the nature of the feed ingredients used in the basal ration, in addition to the breed characteristics of the chickens used. The major feed ingredients of the basal ration were ground yellow corn ( 56 percent), alfalfa-leaf meal ( 5 percent), and corngluten feed ( 5 percent). ${ }^{4}$ Various workers in the continental United States

TABLE 1.-Pigmentation of the various parts of the body of chichens fed a ration with and without achiole-seed supplementation

\begin{tabular}{|c|c|c|c|}
\hline \multirow{2}{*}{ Part of the body } & \multicolumn{2}{|c|}{ Result under treatment indicated } & \multirow{2}{*}{ Trials } \\
\hline & Control & Achiote & \\
\hline Neck & Pale yellow & Bright yellow & $1-2$ \\
\hline Breast & do. & do. & $1-2$ \\
\hline Abdomen & do. & do. & $1-2$ \\
\hline Thigh and leg & do. & do. & $1-2$ \\
\hline Back & do. & do. & $1-2$ \\
\hline Shank & do. & Yellowish orange & 1 \\
\hline Beak & do. & do. & 1 \\
\hline General appearance & $\begin{array}{l}\text { Very light-yellow } \\
\text { pigmentation }\end{array}$ & $\begin{array}{l}\text { Bright-yellow pig- } \\
\text { mentation }\end{array}$ & $1-2$ \\
\hline Carcass fats & Light yellow & Bright yellow & 2 \\
\hline
\end{tabular}

have previously demonstrated that yellow corn, alfalfa-leaf meal, and corngluten meal impart bright pigmentation to the shanks, beaks, and skin of growing chickens $(t, 5,6,9)$.

\section{TRIAL 2}

The degree of pigmentation of chickens in trial 2 followed the same trend as observed in trial 1. Brighter coloration of the various parts of the chicken were noted in the achiote-fed chickens than those corresponding parts of the control chickens (table 1).

Carcasses of chickens fed an achiote-seed-supplemented ration had more vivid skin pigmentation and more distinct fatty color in the adipose regions than observed in the carcasses of control chickens. Deposits around the gizzard, oviduct, and intestines, and abdominal-fat deposition were also

"A corn-gluten feed is a mixture of corn bran and corn-gluten meal. 
deeper yellow in color, in contrast to the matching parts of the control chickens. The results obtained in the present study substantiated an earlier report of Hill and Dansky (7) that most pigment deposition in growing chickens is in the carcass fats.

The higher average body-weight gains of the achiote-fed chickens observed in trial 1 were not substantiated in the second trial. There was no significant difference in growth rate between the two groups (tables 2 and 3).

TABLE 2.-The growth performance of chickens in 3 trials when fed a ration supplemented with achiole seed and canthaxanthin, singly

\begin{tabular}{|c|c|c|c|c|c|c|c|}
\hline \multirow[b]{2}{*}{ Treatments } & \multicolumn{2}{|c|}{ Trial 1} & \multicolumn{2}{|c|}{ Trial 2} & \multicolumn{3}{|c|}{ Trial 3} \\
\hline & Control & Achiote & Control & Achiote & Control & Achiote & $\begin{array}{l}\text { Can- } \\
\text { thax- } \\
\text { anthin }\end{array}$ \\
\hline $\begin{array}{c}\text { Chicks.................... number } \\
\text { Average starting body } \\
\text { weight }{ }^{1} \ldots \ldots \ldots \ldots \ldots \ldots \ldots \text { pounds }\end{array}$ & 1.12 & $\int_{1.15}^{25}$ & 1.69 & 1.67 & $\begin{array}{l}28 \\
1.70\end{array}$ & $\int_{1.50}^{45}$ & $\begin{array}{l}50 \\
1.52\end{array}$ \\
\hline $\begin{array}{l}\text { Average final body weight }{ }^{1} . \\
\text { Average final body weight } \\
\text { gain } \ldots \ldots \ldots \ldots \ldots \ldots \ldots \text { do. } \\
\text { Average daily body weight } \\
\text { gain } \ldots \ldots \ldots \ldots \ldots \ldots \ldots \text { do. }\end{array}$ & $\begin{array}{r}2.51 \\
1.39 \\
.040\end{array}$ & $\begin{array}{r}2.79 \\
1.64 \\
.047\end{array}$ & $\begin{array}{r}3.23 \\
1.54 \\
.055\end{array}$ & $\begin{array}{r}3.39 \\
1.70 \\
.061\end{array}$ & $\begin{array}{r}3.18 \\
1.48 \\
.053\end{array}$ & $\begin{array}{r}3.05 \\
1.50 \\
.054\end{array}$ & $\begin{array}{r}3.01 \\
1.49 \\
.053\end{array}$ \\
\hline
\end{tabular}

1 The starting and final body weights of chickens were obtained at the fifth and ninth week on experiment, respectively.

TABI.E 3.-A nalysis of varianre of the body-weight gains of chickens fed a ration with and without achiote-seed supplementation, in trial 2

\begin{tabular}{l|c|c|c|c}
\hline \multicolumn{1}{c|}{ Variance source } & Degrees of freedom & Sums of squares & Nean square & F value \\
\cline { 2 - 3 } Total & 49 & $1,482.50$ & & \\
Treatments & 1 & 89.78 & 89.78 & 3.091 \\
Error & 48 & $1,392.72$ & 29.02 & \\
\hline
\end{tabular}

1 Not significant.

As the chickens in trial 2 were of the same sex, and were weighed individually, the result is more reliable than the growth data in trial 1. This finding indirates that the observed higher body-weight gains in the achiote-fed rhickens in trial 1 were due to factors other than achiote-seed supplementation of the basal ration.

\section{TRIAL :3}

The pigmentation observations made on the various parts of the chicken carcasses are summarized in the following tabulation, the color for the con- 
trol and the achiote-fed chickens having been pale yellow and bright yellow, respectively, in all cases:

Parls of the body

Shank

Beak

Neck

Breast

Abdomen

Thigh and leg

Back

Cieneral appearance

Carcass fats
Under canthaxanlin supplement

Bright yellow do.

Yellowish orange

Bright yellow

Yellowish orange

do.

do.

Yellowish orange, and very pronounced; more of an orange color in feathered areas

Deep pigmentation toward the orange side

Similar results on degree of pigmentation between the achiote-fed chickens in comparison with the controls were observed.

Canthaxanthin was more effective in enhancing pigmentation in growing chickens than achiote seed. Deeper yellow to orange coloration of the various parts of the chicken carcass was observed in the canthaxanthin-fed chickens, in contrast to mere bright-yellow pigmentation in the achiote group. The color of the feathered areas of the chicken body from the canthaxanthin group was more orange than yellow. This degree of chicken pigmentation is not agreeable to most housewives as they prefer a uniform bright-yellow coloration similar to the one observed in the achiote-fed chickens. Probably a more pleasing and suitable pigmentation could be obtained by reducing the level of canthaxanthin in the chicken ration.

The stimulatory pigmentation effect of canthaxanthin was observed earlier, 3 to 5 days after starting the canthaxanthin-supplemented basal ration. In the achiote group it took at least 10 days before a noticeable brightyellow pigmentation occurred in the beak and shank. The vivid coloration of the skin of chicken in both experimental groups appeared later than the bright-yellow pigmentation of the beak and shank.

The pigmentation produced in the achiote-fed chickens persisted when the chickens were slaughtered 2 weeks after the feeding period. This observation indicates that one can stop feeding archiote seed at least 10 days prior to the slaughter of chickens for human consumption, and still have chickens with the preferred coloration.

Arhiote seed are used commonly in food coloring and as spice for food preparation by the people of Puerto Rico. Therefore, there is little or no danger of toxicity, and there is no need to withhold achiote-seed feeding to chickens immediately prior to slaughtering for human consumption.

The pigmentation obscrved in the canthaxanthin-supplemented chickens persisted as long as 1 month after the termination of the experimental 
feeding period. In some cases a few chickens still possessed the pigmentation, but not as vividly as that observed during the feeding period and up to 10 days later.

\section{SUMMARY AND CONCLUSIONS}

The pigmentation-stimulatory effect of achiote seed and canthaxanthin, singly, was studied in growing chickens, at least 5 weeks of age, fed a ration supplemented with achiote seed. They had a brighter beak, shank, and skin coloration than that shown by the corresponding parts of control chickens. When the chicken carcass was studied for a further degree of pigmentation as between the achiote-fed and the control birds it was observed that the fat deposits and fat deposition around the gizzard, vent, and intestines had more vivid pigmentation in the achiote-fed than in the control chickens.

At the level used, canthaxanthin, a commercial xanthophyll preparation, was more effective in enhancing pigmentation in growing chickens than achiote seed. Deep-yellow to orange coloration of the chicken carcass was observed, and at an earlier time, in contrast to bright-yellow pigmentation in the achiote group which occurred later.

Most housewives prefer broilers with a uniform bright-yellow pigmentation. This finding has a potential commercial significance in Puerto Rico and areas where achiote is grown.

\section{RESUMEN Y CONCLUSIONES}

Se estudió separadamente el efecto estimulante de las semillas del achiote $\mathrm{y}$ el producto químico canthaxanthin para intensificar el colorido de la carne de pollo. Los pollos de cinco semanas que recibieron raciones con semillas de achiote tuvieron un colorido más intenso en el pico, las patas y la piel, que las que no consumieron achiote. Cuando se estudió el caparazón de los pollos para determinar la diferencia en colorido entre los pollos que consumieron achiote y los que no lo consumieron, se observó que las acumulaciones de grasa alrededor de la molleja, del ano y de los intestinos tenían un colorido más intenso en los que consumieron achiote comparados con los que no lo consumieron.

A base de la cantidad usada, el canthaxanthin (derivación comercial del xantophyll) es más eficaz que la semilla de achiote para intensificar el rolorido de los pollos. Se observó en el caparazón de los que consumieron canthaxanthin que el color fue entre amarillo subido y anaranjado y los efectos ocurrieron más temprano, en comparación con el amarillo brillante de los que consumieron achiote. lin estos últimos los efectos ocurrieron más tarde.

Las amas de casa, en su mayoría, prefieren que los pollos tengan un color amarillo brillante que seas uniforme. El hecho comprobado por este estudio 
tiene una significación comercial de gran potencialidad en Puerto Rico y otros lugares donde se cultive el achiote.

\section{LITERATURE CITED}

1. Bird, H. R., Increasing yellow pigmentation in shanks of chickens, Poultry Sci. 22 205-8, 1942.

2. Culton, T. G., and Bird, H. R., Effect of certain protein supplements in inhibiting pigment deposition in growing chicks, Poultry Sci. 20 432, 1941.

3. Day, E. J., and Williams, W. P., Jr., A study of certain factors that influence pigmentation in broilers, Poultry Sci. 37 1373-81, 1958.

4. Fritz, J. C., Wharton, F. D., Jr., and Classen, L. J., influence of feed on broiler pigmentation, Feedsluff $2918,1957$.

5. Hammond, J. C., and Harshaw, H. M., Some factors influencing shank and skin color in the growing chickens, Poullry Sci. $20+37-44,1941$.

6. Heiman, V., and Tigle, L. W., Observations on the shank pigmentation of chick, Poullry Sci. 22 102, 1943.

7. Hill, F. W., and Dansky, L. M., The influence of diet on body composition of growing chicks, Proc. Cornell Nutr. Conf. 27-32, 1951.

8. Landagora, F. T., Effect of feeding achiote seed on egg yolk pigmentation, $J$. Agr. Univ. P. R. 46 91-6, 1962.

9. Ratcliff, R. G., Day, E. J., and Hill, J. E., Broiler pigmentation as influenced by dietary modifications, Poullry Sci. 38 1039-18, 1959.

10. Snedecor, G. W., Statisticial Methods th ed., Iowa State College Press Ames, Iowa, 1950.

11. Titus, H. W., The Scientific Feeding of Chickens, 2nd. ed., Interstate Press, Dansville, Ill. 1947.

12. Waldroup, P. W., Douglas, C. R., McCall, J. T., and Harms, R. H., The effect of santoquin on the performance of broilers, Poultry Sri. 39 1313-17, 1960. 